\title{
STUDI PERILAKU PENGGUNAAN RUANG GANG DI KAMPUNG SERANGAN, KELURAHAN NOTOPRAJAN, KECAMATAN NGAMPILAN, KOTA YOGYAKARTA
}

\author{
Casnugi \\ Program Studi Teknik Arsitektur, Akademi Teknik YKPN Yogyakarta \\ Jl. Gagak Rimang No. 1, Balapan, Yogyakarta \\ Email: casnugi.nugi13@gmail.com
}

\begin{abstract}
Abstrak
Studi lebih lanjut tentang ruang gang di tengah-tengah masyarakat perkampungan perkotaan sangat dibutuhkan, ruang gang dapat dimanfaatkan untuk berbagai kegiatan masyarakat, diantaranya untuk bersosialisasi. Dengan keterbatasan ruang di tengah masyarakat permukiman perkotaan kampung Serangan, kelurahan Notoprajan, kecamatan Ngampilan, kota Yogyakarta, terlihat fenomena perilaku masyarakat yang menggunakan gang untuk kegiatan interaksi sosial, menjemur pakaian, parkir sepeda motor bahkan untuk memasak. Selain digunakan untuk jalur sirkulasi, pengguna ruang gang juga harus berbagi dengan anak-anak yang bermain di gang dan di antara bangunan. Melihat uniknya gang sebagai tempat kegiatan masyarakat, ada perilaku yang perlu diketahui terkait penggunaan ruang gang. Tujuan penelitian ini adalah untuk mengetahui gambaran perilaku warga kampung perkotaan dalam menggunakan gang sebagai ruang interaksi sosial. Metode penelitian menggunakan metode deskriptif kualitatif, yaitu dengan cara melakukan observasi, wawancara, dokumentasi dengan foto-foto, pengukuran, pengamatan dan sketsa-sketsa lingkungan. Dengan demikian, dapat disimpulkan bahwa ada rasa kebersamaan, tenggang rasa, toleransi dalam pemakaian gang. Musyawarah warga di wilayah RT (Rukun Tetangga) merupakan sarana dalam membahas dan memutuskan persoalan-persoalan yang ada di wilayahnya, dilakukan secara berkala dan berjalan baik, yang didasarkan pada nilai kebersamaan. Hubungan sosial dan kekerabatan dengan tetangga sangat penting dan mempengaruhi masyarakat untuk mampu hidup di daerah permukiman kampung kota dengan keterbatasan ruang dan sumber daya lingkungan. Sikap toleransi antar masyarakat di kampung Serangan ini dapat dimanfaatkan untuk tujuan pembangunan. Keterikatan antar anggota masyarakat dapat dikembangkan ke dalam programprogram partisipatif pembangunan untuk penanganan lingkungan permukiman perkotaan khususnya dalam hal penanganan kekumuhan. Sedangkan program perbaikan kampung dapat difokuskan pada penanganan perbaikan fisik. Adanya partisipasi masyarakat ini merupakan salah satu dari kesuksesan program-program pembangunan atau perbaikan kampung kota.
\end{abstract}

Kata kunci: Kampung Serangan, perilaku, penggunaan ruang, gang.

\begin{abstract}
Title: Behavioral Study of Spatial Utilization of Alley in Kampung Serangan, Notoprajan SubDistrict, Ngampilan District, Yogyakarta City

The further study of alley as space in the midst of urban settlement communities is needed. The alley as space be utilized by various community activities as well as for socializing. With the limited available space in the middle of the urban settlement community of Serangan village, Notoprajan sub-district, Ngampilan sub-district, Yogyakarta, there is an apparent phenomenon of multiple community behavior in using the alley such as social interaction, drying clothes, parking a motorcycle and even cooking. Besides being used as circulation path, it makes users of the alley must also share with children who play in the alley and in between buildings. Seeing the uniqueness of the alley as a place for such community activity, the behaviors that need to be known further. The purpose of this study was to describe the behavior of urban village residents in utilizing alley as a space for social interaction. The research method used is descriptive qualitative, namely by conducting observations, interviews, documentation with photographs, measurements, observations and environmental sketches. Thus, it can be further understood that
\end{abstract}


there is a sense of togetherness, tolerance in the utilization or occupying of the aisles. Community deliberations in the RT (Rukun Tetangga) area, are a mean for discussing and deciding around issues in their neigbourhood area. It is held periodically based on shared values and usually run well. Social relations and kinship among the neighbors are very important and it is significantly make the community able to live in relatively limited space and environmental resources. The strong sense of tolerance among communities in the village of Serangan can be used for development purposes. Engagement among community members can be enhanced into participatory development programs for taking care of urban settlement environments, especially in terms of slums. Kampong improvement program can be focused on taking care of physical development. The existence of community participation is one of the key success factor of development programs or improvement of urban kampong.

Keywords: Kampung Serangan, behavior, the using of space, alley.

\section{Pendahuluan}

Serangan adalah salah satu nama kampung yang terletak di kelurahan Notoprajan kecamatan Ngampilan kota Yogyakarta. Kampung ini terdapat 2 RW dan 14 RT. Batas wilayah kampung sebelah utara dibatasi $\mathrm{Jl}$. K.H.A. Dahlan, sebelah timur J1. K.H. Wahid Hasyim, sebelah selatan kampung Gendingan, sebelah barat dibatasi sungai Winongo. Jalan-jalan yang terbentuk antar rumah memiliki ciri jalan kampung yang biasa disebut gang atau disebut juga jalan rukun. Akibat dari tingkat kepadatan yang tinggi, maka sangat minim jumlah ruang bersama untuk masyarakat dan anak-anak. Melalui observasi awal, peneliti melihat adanya kegiatan masyarakat yang menggunakan jalanjalan atau gang-gang di kampung Serangan ini tidak hanya berfungsi sebagai aksesibilitas, namun juga sebagai sarana untuk memenuhi kebutuhan akan sosialisasi/ interaksi sosial, memasak, menjemur pakaian, tempat parkir dan bermain anak-anak.

Kampung Serangan merupakan salah satu kampung di kelurahan Notoprajan yang letaknya di tepi sungai Winongo. Di wilayah RW 1 tepatnya di RT 1 dan RT 5 di bantaran sungai sudah terbangun ruang publik, yang proses pembangunannya dilakukan bersama FKWA (Forum Komunikasi Winongo Asri) dan pemerintah kota Yogyakarta.
Lokasi yang 'strategis' merupakan salah satu potensi lokal yang dimiliki kampung ini yang mestinya dapat digunakan sebagai etalase potensi ekonomi dan budaya kampung. Fungsi ruang saat ini digunakan untuk berdagang oleh masyarakat. Selain itu, ada fasilitas flying fox dan panggung hiburan, tetapi kondisinya tidak terawat sehingga terlihat kumuh. Dilihat dari letaknya, lokasi ini sangat strategis karena dekat dengan jalan besar (Jl. R.E. Martadinata) yang dapat dilihat dari jalan utama.

Keunikan yang lain dari kampung ini adalah gang yang digunakan untuk beragam kegiatan warga. Masyarakat pengguna gang tersebut harus peka untuk dapat berbagi ruang. Bagaimana gang yang demikian sempit ini dapat dengan nyaman dilewati oleh mereka yang berjalan kaki, pengendara sepeda ataupun sepeda motor. Mereka yang mengendarai sepeda atau sepeda motor harus turun dan menuntun kendaraannya. Selain digunakan untuk jalur sirkulasi, pengguna ruang gang juga harus berbagi dengan anak-anak yang bermain di gang dan di antara bangunan. Orang tua biasanya dudukduduk saat sore dan malam hari, berinteraksi di gang atau jalan kampung. Lebar gang yang bervariasi antara 80 centimeter -250 centimeter di kiri dan kanan jalan lingkungan tersebut dibatasi dengan pagar pekarangan atau dinding rumah. 
Melihat uniknya gang sebagai tempat kegiatan warga, maka ada perilaku yang perlu diketahui lebih lanjut terkait penggunaan ruang gang.

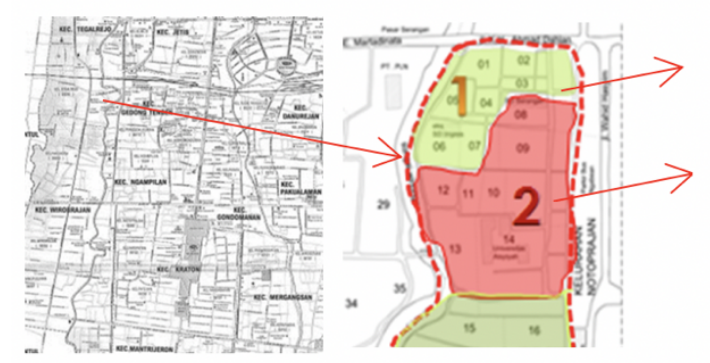

Dengan dasar pertimbangan keunikan gang sebagai aktivitas warga kampung dan potensi yang ada, maka kampung Serangan dipilih sebagai tempat penelitian untuk mengetahui perilaku pengguna gang.

Wilayah RW 1 terdiri dari 7 RT (RT 01 sampai RT 07)

Wilayah RW 2 terdiri dari 7 RT (RT 08 sampai RW 14)

Gambar 1. Peta kampung Serangan RW 1 dan RW 2

Sumber: Analisis peneliti, 2018

Ruang publik di tengah-tengah permukiman masyarakat perkotaan sangat dibutuhkan, namun untuk mencapai kebutuhan tersebut memerlukan pembebasan lahan terhadap rumah warga. Selain itu, dengan kondisi permukiman yang padat dan masih terdapat warga yang kekurangan lahan untuk keperluan MCK, maka alternatif yang selama ini dilakukan masyarakat adalah memanfaatkan gang sekitar permukiman mereka, baik untuk kegiatan pribadi maupun kegiatan bersama. Seperti yang kita ketahui bahwa fungsi gang secara teknis adalah sebagai jalur pergerakan, namun di permukiman kampung perkotaan, fungsi tersebut mengalami penambahan, yaitu sebagai ruang bersama (interaksi sosial), untuk parkir motor, menjemur pakaian dan juga sebagai tempat untuk memasak. Dalam komponen lingkungan permukiman, gang merupakan salah satu jaringan penting yang akan menghubungkan antar permukiman. Sehingga, dalam melihat permasalahan yang ada di kampung Serangan, muncul pertanyaan sejauh mana interaksi sosial di gang lingkungan mempengaruhi kondisi lingkungan permukiman yang digunakan sebagai ruang interaksi sosial oleh warga.

Penelitian ini bertujuan untuk mengetahui gambaran perilaku warga kampung perkotaan dalam menggunakan gang sebagai ruang kegiatan warga dan interaksi sosial. Manfaat penelitian ini diharapkan dapat memberikan sumbangan terhadap konsep penataan ruang publik pada kawasan permukiman padat. Hasil penelitian ini juga diharapkan dapat menjadi sumber pustaka ilmiah dalam perencanaan perumahan/ permukiman. Secara praktis, penelitian ini diharapkan menjelaskan fenomena gang sebagai ruang interaksi sosial yang mencerminkan uniknya budaya masyarakat.

Ruang lingkup penelitian dibatasi oleh ruang lingkup spasial dan substansial. Ruang lingkup spasial merupakan lingkup keruangan pada subyek wilayah yang dikaji dengan batas-batas administrasinya, sedangkan ruang lingkup substansial merupakan elemen-elemen dasar obyek studi yang menjadi bahan pertimbangan dalam identifikasi wilayah. 


\section{Ruang Lingkup Spasial}

Ruang lingkup spasial dari penelitian ini adalah wilayah kampung Serangan (RW 01 dan RW 02), kelurahan Notoprajan, kecamatan Ngampilan, kota Yogyakarta. Untuk dapat memperoleh hasil yang tepat sasaran, maka cakupan wilayah penelitian dipersempit pada RW 01 saja.

\section{Ruang Lingkup Substansial}

Batasan substansial yang menentukan lingkup penelitian disesuaikan dengan sasaran penelitian. Batasan-batasan penelitian ini akan terbatas pada proses pencapaian tujuan sehingga pembahasan proses penelitian akan berjalan lebih efektif. Berkaitan dengan tujuan penelitian yang ingin dicapai, maka batasan penelitian adalah sebagai berikut:

1. Karakteristik sosial masyarakat, digunakan untuk menjelaskan karakteristik sosial warga yang memanfaatkan gang sebagai ruang interaksi sosial. Materi yang terkait dengan karakteristik sosial pengguna yaitu jenis kelamin, lama bermukim, mata pencaharian dan tingkat Pendidikan.

2. Karakteristik bentuk interaksi sosial masyarakat di gang permukiman kampung Serangan, digunakan untuk mengetahui interaksi apa saja yang dilakukan masyarakat di gang, melalui kegiatan-kegiatan yang dilakukan oleh masyarakat. Hal ini bertujuan untuk mengetahui karakteristik fungsi gang yang digunakan sebagai ruang interaksi sosial, yaitu interaksi masyarakat yang terjadi di ruang publik yang meliputi jenis kegiatan, waktu kegiatan, alasan dan kenyamanan masyarakat dalam melakukan interaksi sosial.

3. Kondisi fisik lingkungan permukiman yang terkait dengan gang, yaitu kondisi fisik jalan permukiman, kondisi fisik drainase dan kebersihan lingkungan permukiman.

4. Pengaruh gang sebagai ruang interaksi sosial terhadap lingkungan permukiman, diketahui dari hasil analisis karakteristik, bentuk kegiatan masyarakat terhadap kondisi fisik gang, kebersihan lingkungan permukiman dan kondisi sosial masyarakat. Pemilihan aspek-aspek lingkungan permukiman ini didasari oleh permasalahan yang ada di lingkungan permukiman, yaitu gang digunakan sebagai ruang interaksi sosial. Komponen lingkungan permukiman yang memiliki hubungan dengan permasalahan tersebut adalah network, yaitu jaringan jalan dan gang (dilihat dari segi fisik jalan, fisik drainase, kebersihan) dan masyarakat (kondisi sosial masyarakat sebagai akibat yang ditimbulkan oleh interaksi sosial).

\section{Metode Penelitian}

Penelitian ini bertujuan untuk menganalisis kajian pola perilaku dan pemanfaatan ruang gang di kampung kota secara induktif menggunakan berbagai informasi melalui hasil observasi dan wawancara di lapangan. Penelitian ini berkaitan dengan problem perilaku dengan lingkungannya, perilaku individu maupun kelompok (lebih dari satu orang).

Untuk itu, metode yang digunakan adalah metode deskriptif kualitatif, dengan cara melakukan observasi untuk melihat kegiatan di lokasi penelitian. Dalam penelitian kualitatif pengamatan dilakukan secara holistik dalam setting alamiah, peneliti tidak memiliki asumsi tentang subyek yang diteliti secara apriori. Tujuan dari penelitian kualitatif adalah 
menghasilkan deskripsi yang kaya dan membangun teori dari hasil temuan di lapangan yang bersifat kontekstual (Sudradjat, 2016).

\section{Metode Pengumpulan Data}

Survey lapangan dilakukan untuk mendapatkan data melalui pengamatan, pengukuran dan dokumentasi. Data yang diperoleh berupa aktivitas warga, kondisi ruang terbuka dan pola ruang gang. Karena penelitian ini bertujuan untuk menganalisis pengaruh fungsi gang, sebagai ruang interaksi sosial terhadap lingkungan permukiman kampung Serangan, kelurahan Notoprajan, kecamatan Ngampilan, kota Yogyakarta, maka strategi penelitian survey berusaha memaparkan secara kuantitatif kecenderungan sikap atau opini dari suatu populasi tertentu dengan meneliti satu sampel dari populasi tersebut. Penelitian survey menggunakan kuesioner terbuka dan kuesioner tertutup atau wawancara terencana dalam pengumpulan data, dengan tujuan untuk menggeneralisasi populasi berdasarkan sampel yang sudah ditentukan (Babbie dalam Cresswell, 2010:19).

Observasi partisipatif didefinisikan sebagai suatu proses dimana pengamat atau observer hadir dalam situasi hubungan langsung dengan yang diamati dengan berperan serta dalam kegiatan sehari-hari observer mengumpulkan data (McCall and Simmons, 1969). Sedangkan Behavioral mapping merupakan teknik survey yang dapat dipakai dalam kajian arsitektur lingkungan dan perilaku yang dikembangkan oleh Ittelson sejak tahun 1970. Dengan teknik ini akan didapatkan suatu bentuk informasi mengenai suatu fenomena (terutama perilaku individu dan sekelompok manusia) yang terkait dengan sistem spasialnya. Behavioral mapping digambarkan dalam bentuk sketsa atau diagram mengenai suatu area dimana manusia melakukan berbagai kegiatan (Sommer 1969).

\section{Hasil dan Pembahasan}

Arsitektur Lingkungan dan Perilaku

Behavior setting dapat diartikan secara sederhana sebagai suatu interaksi antara suatu kegiatan dengan tempat yang spesifik. Dengan demikian, behavior setting mengandung unsurunsur sekelompok orang yang melakukan suatu kegiatan, aktivitas atau perilaku dari sekelompok orang tersebut, tempat dimana kegiatan tersebut dilakukan, serta waktu spesifik saat kegiatan tersebut berlangsung.

Dalam studinya tentang perilaku anakanak di berbagai lokasi yang berbeda, misalnya tempat bermain, Barker, pelopor kajian ecological psychology, bersama Wright pada tahun 1950-an menemukan pola perilaku yang unik dan spesifik terkait dengan unsur-unsur fisik atau setting yang ada.

Berdasarkan studi ini, mereka mengembangkan metode behavior setting untuk mengkaji kaitan antara perilaku dan sistem setting. Hasil-hasil kajian mereka kemudian dituangkan oleh Barker dalam buku yang cukup monumental dibidang kajian arsitektur lingkungan dan perilaku yakni ecological psychology (Barker, 1968). Apa yang menjadi penekanan dalam kajian behavior setting adalah bagaimana kita dapat mengidentifikasikan perilaku-perilaku yang secara konstan atau berkala muncul pada satu situasi tempat atau setting tertentu.

Setelah psikologi berkembang luas dan dituntut mempunyai ciri-ciri suatu disiplin ilmu pengetahuan maka jiwa dipandang terlalu abstrak. Sementara itu, ilmu pengetahuan menghendaki 
obyeknya bisa diamati, dicatat dan diukur. Hal ini membawa J.B. Watson (1878-1958) memandang psikologi sebagai ilmu yang mempelajari tentang perilaku karena perilaku dianggap lebih mudah diamati, dicatat dan diukur. Arti perilaku mencakup perilaku yang kasat mata, seperti makan, menangis, memasak, melihat, bekerja dan perilaku yang tidak kasat mata, seperti fantasi, motivasi dan proses yang terjadi pada waktu seseorang diam atau secara fisik tidak bergerak (Laurens, 2004: 19).

Sebagai obyek studi empiris, Laurens (2004) mengatakan bahwa perilaku mempunyai ciri-ciri sebagai berikut:

1. Perilaku itu sendiri kasat mata, tetapi penyebab terjadinya perilaku secara langsung mungkin tidak dapat diamati.

2. Perilaku mengenal berbagai tingkatan, yaitu perilaku sederhana dan stereotip, seperti perilaku binatang bersel satu; perilaku kompleks seperti perilaku sosial manusia; perilaku sederhana seperti refleks, tetapi ada juga yang melibatkan proses mental biologis yang lebih tinggi.

3. Perilaku bervariasi dengan klasifikasi: Kognitif, afektif dan psikomotorik, yang menunjuk pada sifat rasional, emosional dan gerakan fisik dalam berperilaku.

4. Perilaku bisa disadari dan bisa juga tidak disadari.

Latar belakang ilmu perilaku lingkungan diawali oleh studi dari dua tokoh yaitu Kurt Lewin (1890-1947) dan Egon Brunswik (1903-1955). Brunswik yang dilahirkan di Budapest dan dibesarkan di Vienna, percaya bahwa lingkungan fisik mempengaruhi manusia tanpa manusia sendiri menyadarinya. Brunswik inilah orang pertama yang menggunakan istilah psikologi-lingkungan. Sedangkan Kurt
Lewin, seorang penganut psikologi Gestalt, yang dilahirkan di Prussia dan menjalani pendidikan di Jerman, merupakan salah seorang tokoh yang pertama kali memberi pertimbangan terhadap pengaruh lingkungan fisik pada perilaku manusia. Ia membuat rumusan bahwa tingkah laku $(B=$ behavior) merupakan fungsi dari keadaan pribadi seseorang $(P=$ person) dan lingkungan tempat orang itu berada $(E=$ environment $)$ atau $\mathrm{B}=$ $\mathrm{f}(\mathrm{P}, \mathrm{E})$ (Laurens, 2004: 20).

Untuk menjelaskan definisi behavior setting, Roger Barker mengembangkan pengujian struktur dan tingkat interdependensi dari behavior setting. Behavior setting didefinisikan sebagai suatu kombinasi yang stabil antara aktivitas, tempat dan kriteria sebagai berikut:

1. Terdapat suatu aktivitas yang berulang, berupa suatu pola perilaku (standing pattern of behavior). Dapat terdiri atas satu atau lebih pola perilaku ekstraindividual.

2. Dengan tata lingkungan tertentu (circumjacent milieu), milieu ini berkaitan dengan pola perilaku.

3. Membentuk suatu hubungan yang sama antar keduanya (synomorphy).

4. Dilakukan pada periode waktu tertentu.

(Laurens, 2004: 175).

Untuk mengetahui sejauh mana interdependensi antara dua entitas, yang masing-masing mempunyai atribut untuk menjadi sebuah behavior setting, apakah mereka dapat dikatakan merupakan satu atau dua behavior setting, dapat dilakukan pengujian. Pengujian derajat ketergantungan ini ditinjau dalam berbagai dimensi antara lain meliputi:

1. Aktivitas

2. Penghuni

3. Kepemimpinan 
Dengan mengetahui posisi fungsional penghuni, dapat diketahui peran sosial yang ada dalam komunitas tersebut. Siapa berperan sebagai pemimpin. Siapa yang mengarahkan acara atau kegiatan dalam setting. Atau siapa yang mengendalikan behavior setting. Di banyak setting, posisi pemimpin dapat dipisahkan agar dapat dikenali kekuatan-kekuatan lain yang ada yang ikut mengambil bagian dalam setting tersebut.

4. Populasi

Sebuah setting dapat mempunyai banyak atau sedikit partisipan. Komunitas dianggap lebih baik apabila memiliki banyak setting. Penghuninya bisa ikut aktif berpartisipasi dan tidak atas perintah atau pengarahan pemimpinnya saja.

5. Ruang

Ruang tempat terjadinya setting tentu sangat beragam, bisa di ruang terbuka atau ruang tertutup.

6. Waktu

Kelangsungan sebuah setting dapat terjadi secara rutin atau sewaktuwaktu saja. Misalnya, apel pagi tentara yang dilakukan setiap pagi atau sebuah perayaan upacara tujuh belas Agustus. Durasi pada setting yang sama dapat berlangsung sesaat atau terus-menerus sepanjang tahun, misalnya pertokoan.

7. Obyek

8. Mekanisme perilaku

(Laurens, 2004: 179-180).

Sedangkan batas suatu behavior setting adalah di mana perilaku tersebut berhenti. Sistem aktivitas dalam sebuah lingkungan terbentuk dari rangkaian sejumlah behavior setting. Dalam pengamatan behavior setting, dapat dilakukan analisis melalui beberapa cara, antara lain sebagai berikut:

1. Menggunakan time budget
Time budget memungkinkan orang mengurai/ mendekomposisikan suatu aktivitas sehari-hari, aktivitas mingguan atau musiman, ke dalam seperangkat behavior setting yang meliputi hari kerja mereka, atau gaya hidup mereka (Michelson dan Reed, 1975 dalam Laurens, 2004). Fungsi dari time budget adalah untuk memperlihatkan bagaimana seorang individu mengkonsumsi atau menggunakan waktunya.

Informasi ini meliputi hal-hal sebagai berikut:

- Jumlah waktu yang dialokasikan untuk kegiatan tertentu, dengan variasi waktu dalam sehari, seminggu, atau semusim.

- Frekuensi dari aktivitas dan jenis aktivitas yang dilakukan.

- Pola tipikal dari aktivitas yang dilakukan.

(Laurens, 2004: 185).

2. Melakukan sensus

Sensus adalah istilah yang dikemukakan oleh para ahli psikologi lingkungan untuk menggambarkan proses pembelajaran semua aktivitas seorang individu dalam waktu tertentu dengan metode pengamatan.

Hal yang dapat mewakili data pengamatan behavior setting meliputi:

- Manusia (siapa yang datang, ke mana dan mengapa, siapa yang mengendalikan setting?)

- Karakteristik ukuran (berapa banyak orang per jam ada di dalam setting, bagaimana ukuran setting secara fisik, berapa sering dan berapa lama setting itu ada?)

- Obyek (ada berapa banyak obyek dan apa jenis obyek yang dipakai dalam setting, kemungkinan apa 
saja yang ada bagi stimulasi, respons dan adaptasi?)

- Pola aksi (aktivitas apa yang terjadi di sana, seberapa sering terjadi pengulangan yang dilakukan orang?)

(Laurens, 2004: 186).

Teritorialitas (territoriality), seperti halnya ruang personal, teritorialitas merupakan perwujudan 'ego' seseorang karena orang tidak ingin diganggu, atau dapat dikatakan sebagai perwujudan dari privasi seseorang. Jika kita amati lingkungan di sekitar kita dengan mudah, akan kita dapati indicator teritorialitas manusia seperti papan nama, pagar batas, atau papan pengumuman yang mencantumkan kepemilikan suatu lahan. Julian Edney (1974) dalam Laurens (2004) mendefinisikan teritorialitas sebagai sesuatu yang berkaitan dengan ruang fisik, tanda, kepemilikan, pertahanan, penggunaan yang eksklusif, personalisasi dan identitas. Termasuk di dalamnya dominasi, kontrol, konflik, keamanan, gugatan akan sesuatu dan pertahanan.

\section{Perilaku Warga dalam} Menggunakan Gang

Perilaku warga dalam menggunakan gang kampung Serangan disajikan dalam gambar berikut:

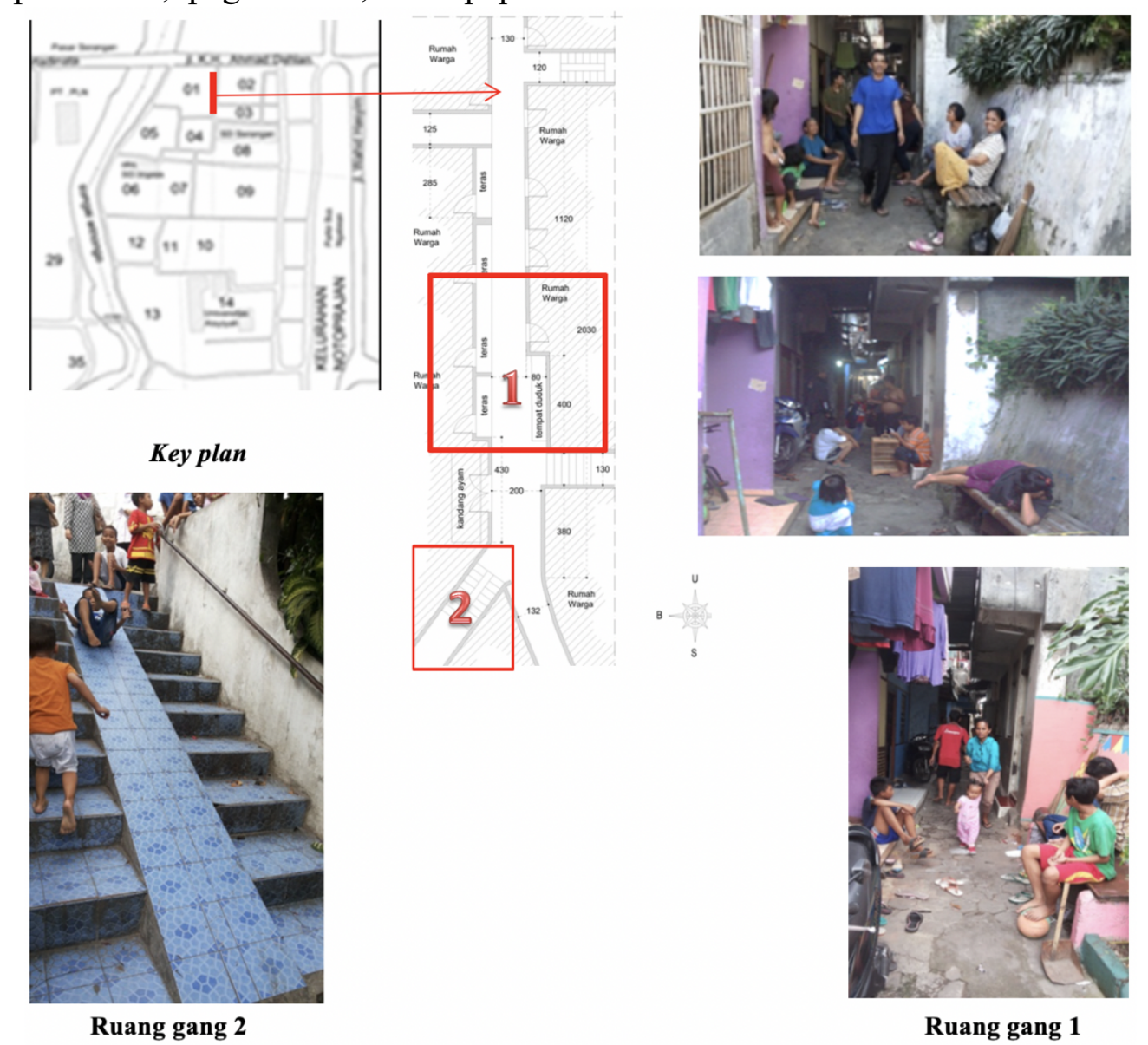

Gambar 2. Ruang gang wilayah RT 01 dan 02, RW 01 Sumber: Hasil analisis, 2018 
Pada ruang gang 1, warga berinteraksi dengan tetangga di gang, duduk-duduk sambil bercakap-cakap, tempat duduk terkadang digunakan untuk tiduran dan anak-anak juga bermain di area gang tersebut. Warga membuat hiasan (mural pada dinding) di belakang tempat duduk, sehingga suasana ruang menjadi bersih dan menarik. Ketika gang dalam keadaan sepi, anak-anak menggunakan gang untuk bermain bola, tetapi orang yang lewat gang tersebut tampak tidak terganggu. Warga juga menjemur pakaian yang digantung di bawah atap teritisan teras rumah.

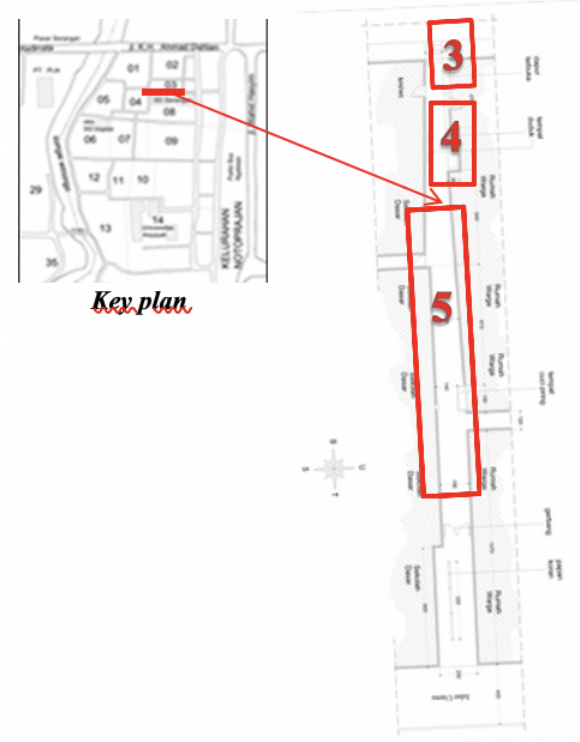

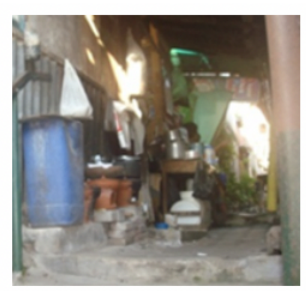

Ruang gang 3
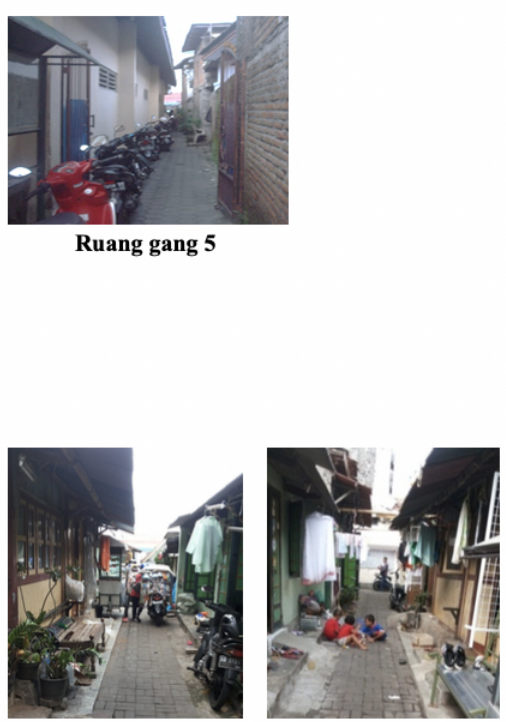

Ruang,gang 6

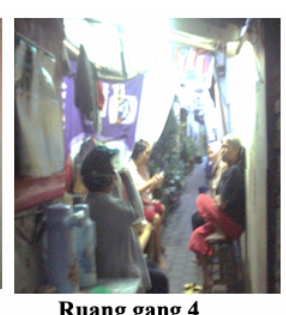

Ruang gang 4

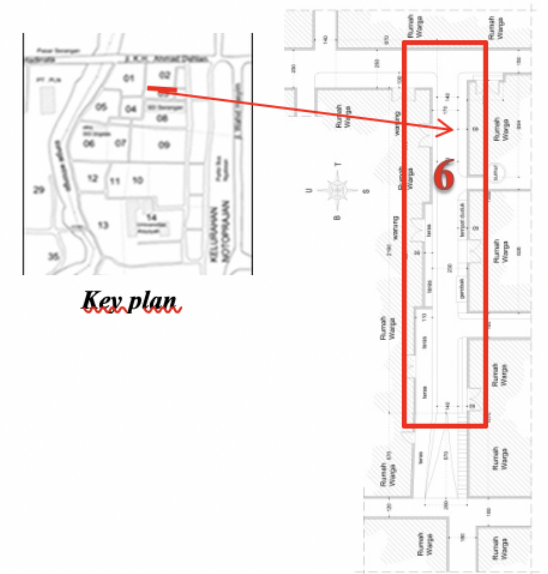

Pada ruang gang 2, anak-anak bermain (prosotan) dengan tidak memperhatikan keselamatan dan beresiko jatuh. Tempat untuk bermain ini sebenarnya diperuntukkan sebagai jalur naik turun untuk menuntun sepeda warga yang lewat di gang tersebut. Dengan kemiringan yang sangat curam dengan bahan keramik yang permukaannya licin tentu saja dapat membahayakan bagi yang melewatinya.

Gambar 3. Ruang gang wilayah RT 03, RW 01 Sumber: Hasil analisis, 2018 
Beberapa kegiatan warga yang terdokumentasi adalah warga memasak di tepi gang pada ruang gang 3, warga berinteraksi dengan tetangga (mengobrol dan bersantai) pada ruang gang 4, warga menggunakan gang untuk parkir motor tamu maupun warga pada ruang gang 5. Motor-motor warga diparkir di gang sampai larut malam, bahkan oleh warga gang ini digunakan untuk 'garasi' motor karena pintu gang dikunci ketika jam 10

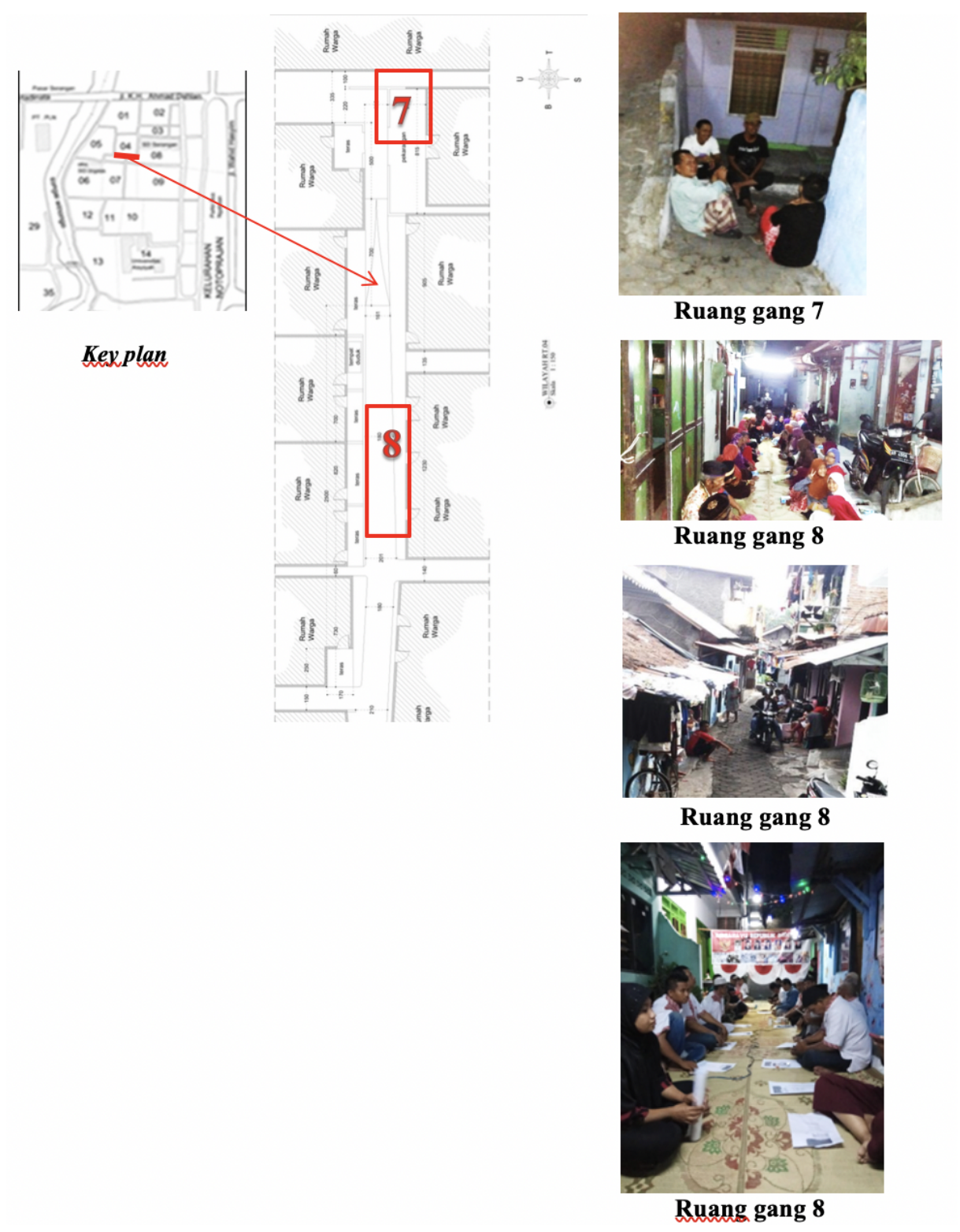

malam. Sedangkan pada ruang gang 6 , anak-anak bermain di gang. Gerobak dan kursi panjang yang ditempatkan di tepi gang digunakan untuk dudukduduk pada sore dan malam hari. Orang yang melewati gang harus turun dan mematikan mesin motornya. Selain itu, pada ruang gang 6 ini juga terdapat warga yang menjemur pakaian dengan digantung pada teritisan atap.

Gambar 4. Ruang gang wilayah RT 04, RW 01

Sumber: Hasil analisis, 2018 
Ruang gang 7 ini terletak di sudut pertemuan dua gang, letaknya yang tinggi menyebabkan ketika kita berada di ruang ini bisa memandang/ melihat suasana gang tanpa terganggu. Arah angin juga tidak terhalang apapun, sehingga ketika kita duduk di tempat ini akan terasa sejuk karena hembusan angin. Ruang ini setiap hari digunakan oleh warga ketika sore dan malam hari.

Ruang gang 8 dapat dikatakan sebagai ruang multifungsi. Oleh karena warga

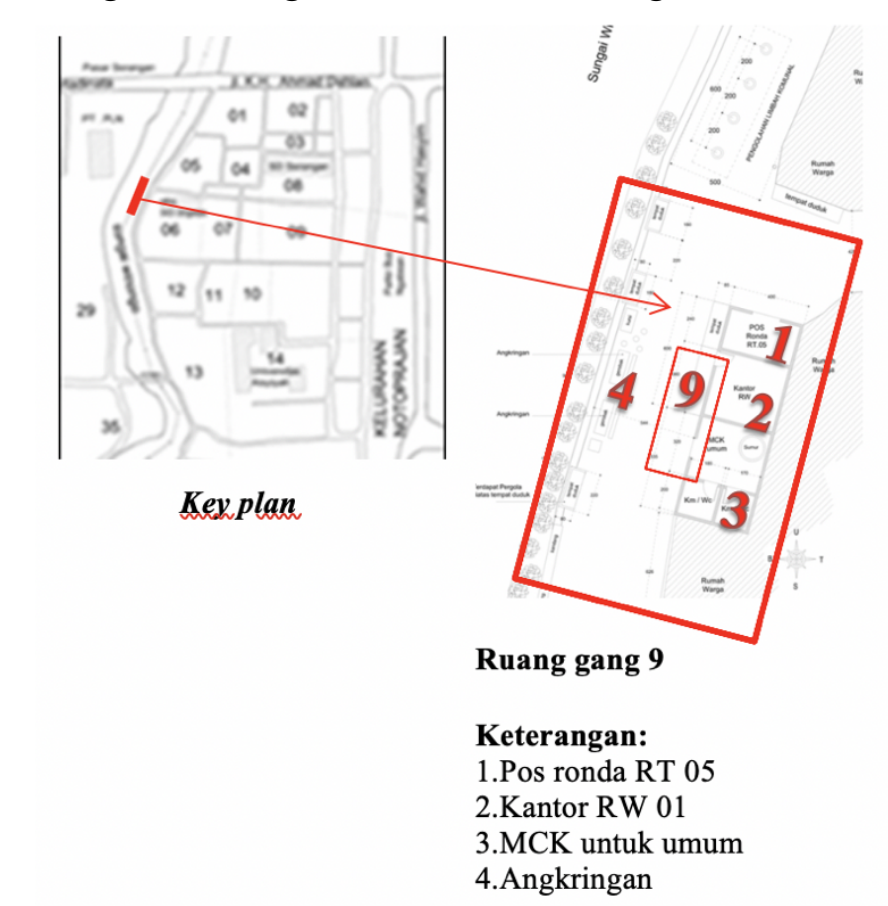

kesulitan untuk mencari ruang yang dapat menampung kegiatan warga dengan jumlah yang banyak, maka warga menggunakan gang ini untuk berbagai kegiatan seperti pengajian, malam tirakatan HUT RI dan juga rapat warga. Dengan demikian, gang yang fungsi utamanya sebagai jalur sirkulasi pejalan kaki, digunakan untuk fungsi lainnya sehingga gang ini bernilai meaningful dan democratic.
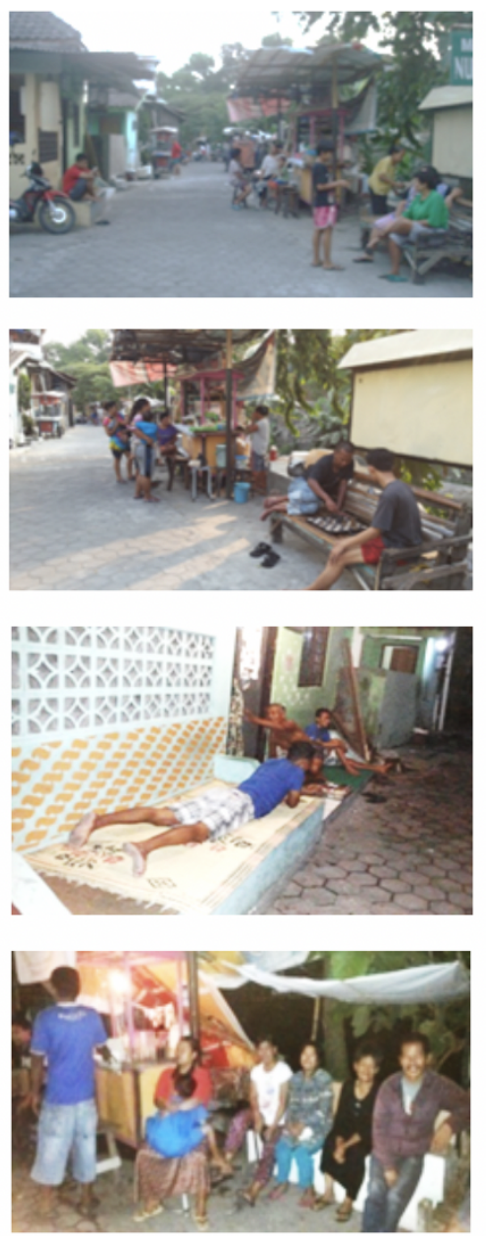

Gambar 5. Ruang gang wilayah RT 05, RW 01

Sumber: Hasil analisis, 2018

Pada ruang gang 9, aktivitas warga pada sore hari adalah duduk-duduk di teras pos ronda RT 05 , terkadang ada juga yang menunggu antri di MCK umum. Sedangkan angkringan yang terletak di depan kantor RW 01 menjadi pusat kuliner warga. Pada sore hari warga membeli makanan dan minuman di angkringan dan anak-anak muda bermain catur. Pada malam hari warga menggunakan teras pos ronda dan teras kantor RW 01 untuk bersosialisasi dan makan/ minum di angkringan. Dengan demikian, tempat- 
tempat yang sering digunakan untuk berkumpul warga adalah teras kantor RW 01, teras pos ronda, pos ronda,

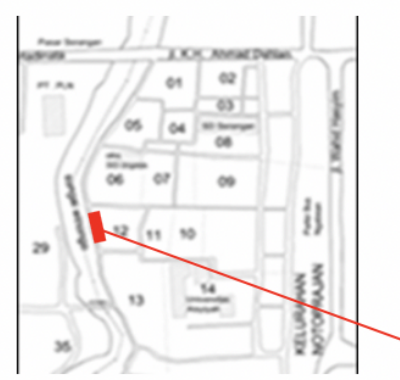

Kexplan tempat duduk di tepi sungai dan angkringan.
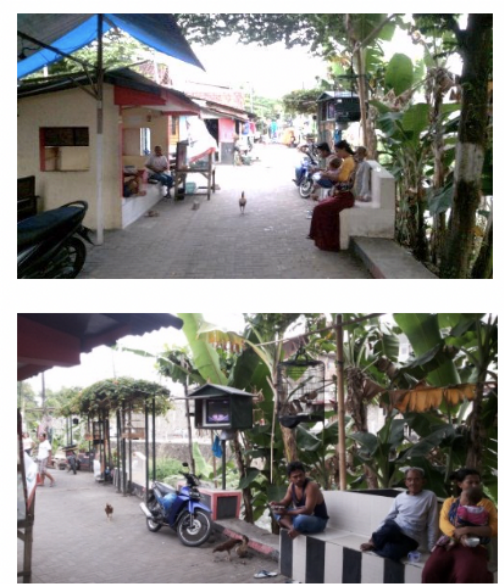

Ruang 1 (tempat duduk)

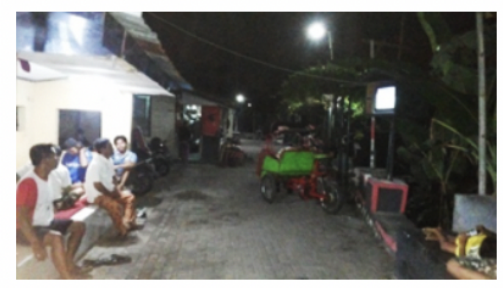

Ruang 2 (pos ronda)

Ruang 3 (tempat televisi)

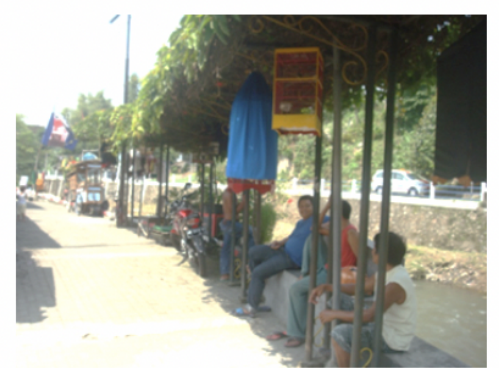

Ruang 4 (tempat duduk di tepi sungai Winongo)

Gambar 6. Ruang gang wilayah RT 12, RW 02

Sumber: Hasil analisis, 2018

Pada ruang gang 10, warga bersantai dan bersosialisasi di depan pos ronda RT 12 dan sekaligus digunakan untuk berdagang. Ketika malam hari, warga masih melakukan aktivitas berkumpul sambil melihat televisi sebagai sarana hiburan yang merupakan milik warga dan sebagian bermain catur di pos ronda RT 12, RW 02. Sebagian warga juga bersantai di tempat duduk di tepi sungai Winongo. Dari berbagai aktivitas ini terlihat bahwa kebersamaan warga sangat tinggi di wilayah ini. 

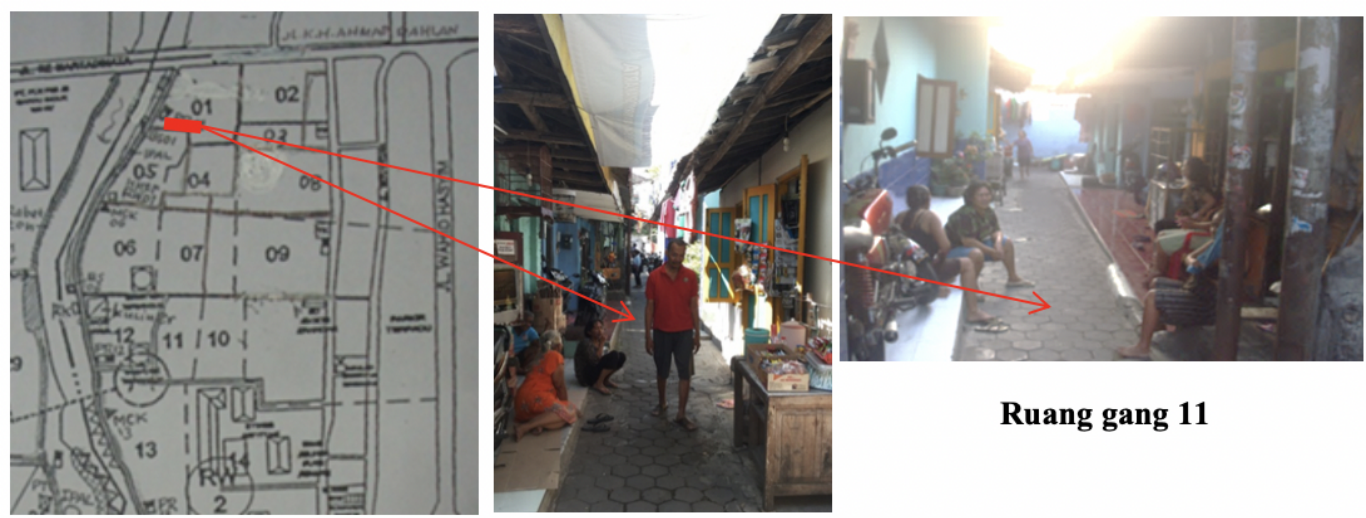

Ruang gang 11

Gambar 7. Ruang gang wilayah RT 05 dan RT 01

Sumber: Hasil analisis, 2018

Gang di RT 01 dan RT 05 ini secara administrasi merupakan batas wilayah RT 05 dengan RT 01, RW 01. Suasana di gang ini terlihat warga berinteraksi dengan tetangga, duduk-duduk di teras di tepi gang sambil mengobrol, ketika ada warga yang lewat di gang dan sudah saling mengenal biasanya saling menyapa, tetapi ketika mereka tidak saling mengenal, biasanya yang lewat 'menghormat' (permisi atau nuwun sewu sambil menundukan kepala dan punggung) pada warga yang sedang duduk-duduk. Gang ini juga digunakan warga untuk berdagang (jualan es dan jajanan lainnya).
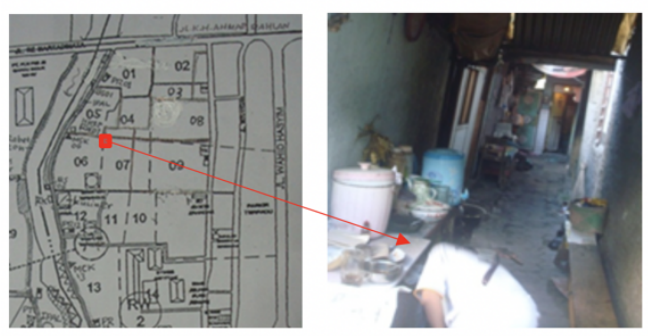

Gambar 8. Ruang gang 12, RT 04 RW 01 Sumber: Hasil analisis, 2018

Warga menggunakan ruang gang 12 untuk memasak dalam rangka memenuhi kebutuhan warungnya (berdagang gorengan, minuman teh, mie kopyok). Waktu memasak biasanya mulai pukul 08.00 WIB sampai dengan 17.00 WIB. Gang ini menjadi ruang public, dimana warga berinteraksi membeli makanan dan minuman, berbincang-bincang, duduk di teras rumah di tepi gang. Hal ini merupakan interaksi sosial dengan waktu yang lama.

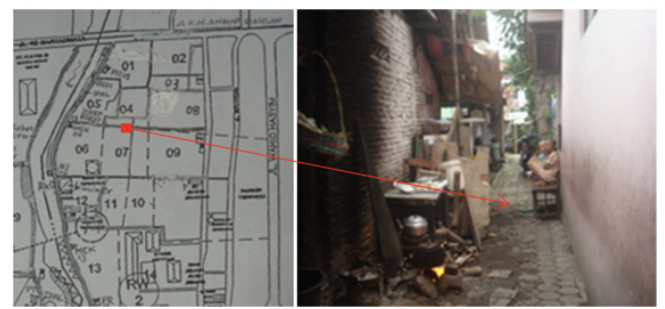

Gambar 9. Ruang gang 13, RT 07 RW 01 Sumber: Hasil analisis, 2018

Pada ruang gang 13, warga juga menggunakan tepi gang untuk memasak sambal berinteraksi dengan tetangganya.

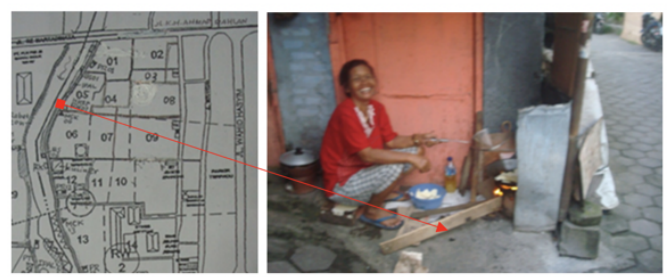

Gambar 10. Ruang gang 14, RT 05 RW 01 Sumber: Hasil analisis, 2018

Di ruang gang 14 warga juga menggunakan tepi gang untuk tempat memasak. Dari gambar 8,9,10 di atas dan hasil observasi menandakan bahwa ada keterbatasan ruang untuk 
mewadahi aktivitas kegiatan keluarga di dalam rumah tinggalnya, sehingga warga menggunakan tepi gang untuk tempat memasak. Gang pada awalnya dibuat sebagai jalur sirkulasi tetapi pada akhirnya digunakan untuk tempat memasak. Lebar gang 120 centimeter sangat tidak nyaman ketika dilewati banyak orang, tetapi gang ini dianggap democratic bagi pengguna karena gang ini dapat digunakan untuk berbagai macam kegiatan.

\section{Pemetaan Perilaku (Behavioral Mapping) Warga Menggunakan Gang di RT 01 dan 02, RW 01}

Setting kegiatan warga di gang wilayah RT 01 dan RW 01 ini memiliki pola rumah yang saling berhadapan dengan gang sebagai batas muka antar rumah. Dengan keterbatasan ruang yang ada di rumah, warga mengunakan gang untuk melakukan berbagai kegiatan (bersantai, bercakap-cakap dan bermain). Kegiatan tersebut biasa dilakukan pada sore dan malam hari. Sedangkan anak-anak bermain pada sore hari, tetapi ketika libur sekolah anak-anak bermain di pagi, siang dan sore hari. Lebar gang bervariasi sekitar $130 \mathrm{~cm}, 140 \mathrm{~cm}$ dan $200 \mathrm{~cm}$, namun gang dapat digunakan berbagai kegiatan sebagai ruang publik. Secara responsive gang ini digunakan untuk jalur sirkulasi, tetapi gang ini mempunyai nilai meaningful karena digunakan berulang-ulang oleh warga untuk sekedar duduk-duduk dan juga anak-anak bermain.

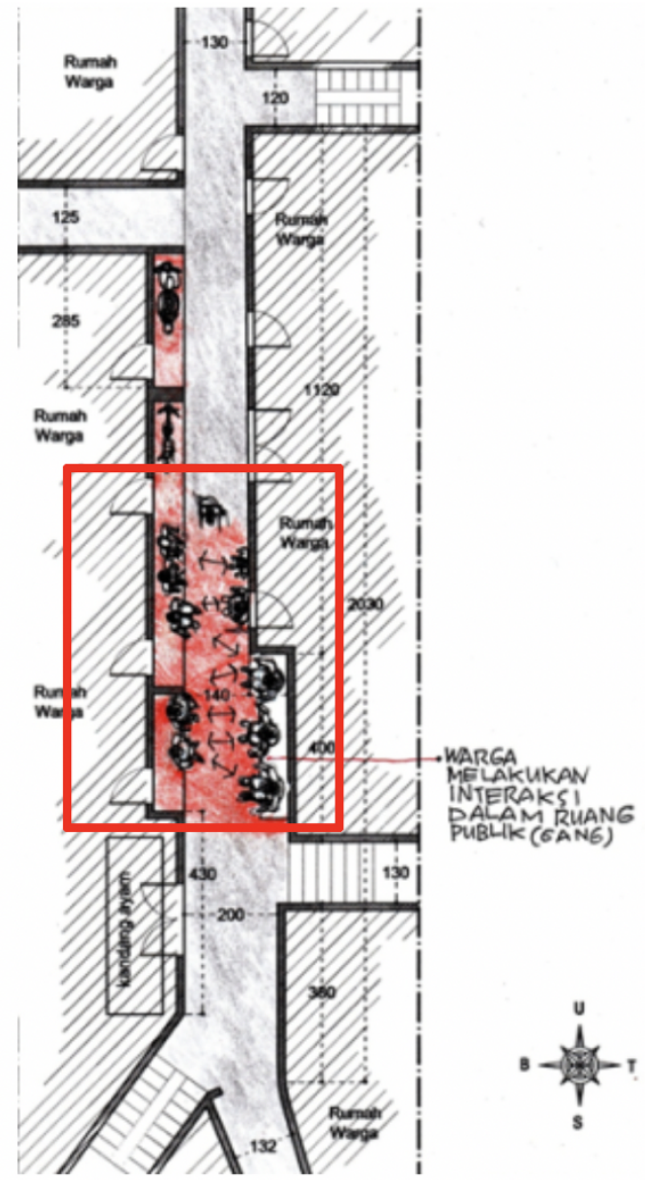

Gambar 11. Setting warga menggunakan gang

Sumber: Hasil analisis, 2018

\section{Pemetaan Perilaku (Behavioral Mapping) Warga Menggunakan Gang di RT 03, RW 01}

Warga menggunakan gang sebagai tempat parkir, disebabkan karena ruang di dalam rumah tidak mencukupi dan tidak bisa menampung kegiatan rumah tangganya, termasuk untuk memarkir motornya. Faktor lainnya yang menyebabkan warga menggunakan gang sebagai tempat parkir adalah wilayah ini memiliki tanah yang berkontur, gang yang sempit, warga yang rumahnya masuk ke dalam kampung harus berputar jauh untuk sampai ke rumahnya, sehingga warga memilih untuk memarkir motornya di tempat ini (lihat gambar 12) dan selanjutnya mereka berjalan kaki menuju ke rumahnya. 
Gang ini bahkan sebagai garasi motor warga. Pada gang ini dibuat pintu dan ketika malam sekitar pukul 22.00 WIB pintu ini terkunci, sedangkan akses untuk pejalan kaki dialihkan di gang yang lain. Lebar gang bervariasi sekitar $110 \mathrm{~cm}, 140 \mathrm{~cm}, 155 \mathrm{~cm}$ dan $190 \mathrm{~cm}$. Pengguna gang/ pejalan kaki harus berbagi ruang dengan sepeda motor yang diparkir di sepanjang gang, dengan kondisi gang yang tidak cukup comfort ketika dilalui banyak orang. Dengan demikian, ketika gang digunakan untuk berbagai macam kegiatan maka gang ini cukup democratic.

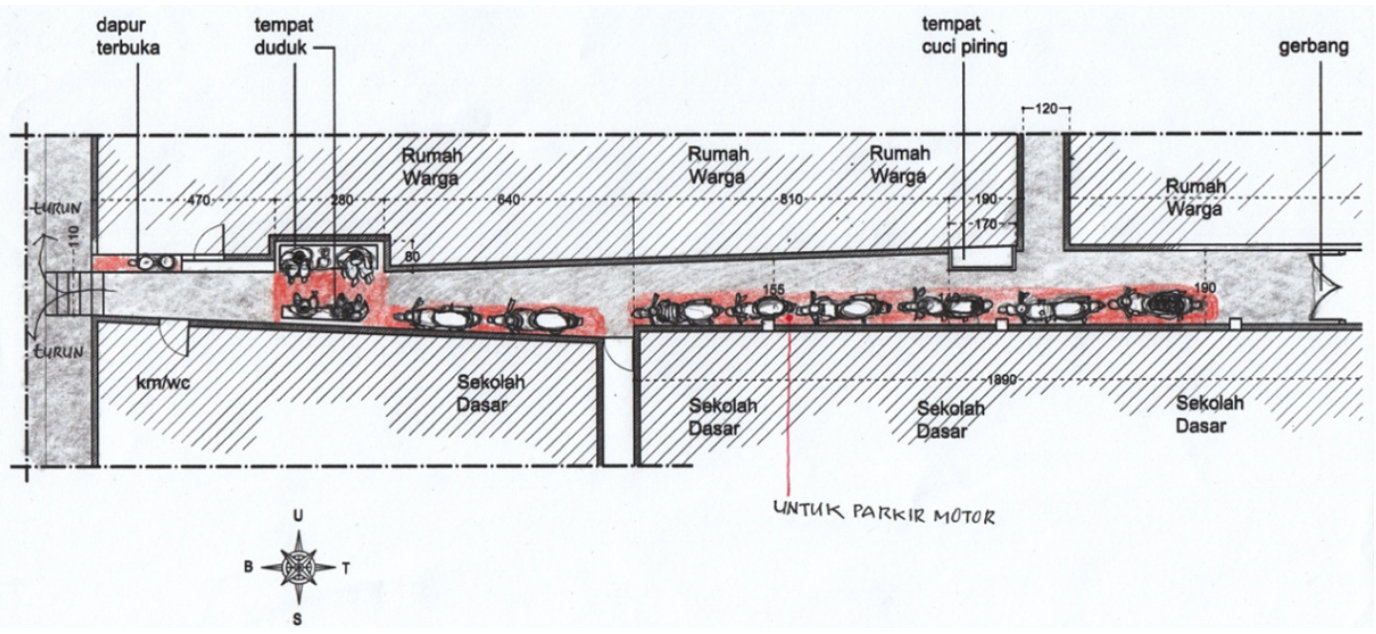

Gambar 12. Pemetaan perilaku warga menggunakan gang di RT 03, RW 01 (gang sebagai garasi motor)

Sumber: Hasil analisis, 2018

Setting warga menggunakan gang adalah ketika warga menggunakan gang (untuk pertemuan RT, pengajian, malam tirakatan menyambut HUT RI) dan kegiatan lainnya. Ketika kegiatan berlangsung mereka duduk saling berhadapan.Waktu kegiatan ini biasanya malam hari pukul 19.30 WIB sampai dengan pukul 22.30 WIB. Lebar gang $140 \mathrm{~cm}$, sehingga warga duduk saling berhadapan dan tikar sebagai alas duduk dan lama kegiatan tergantung acaranya. Ketika acara pengajian atau rapat warga biasanya sampai jam sepuluh malam dan ketika kegiatan malam tirakatan biasanya sampai jam dua belas malam.Walaupun lebar jalan tidak cukup comfort untuk dilalui oleh banyak orang, tetapi jika gang ini kita lihat dari berbagai kegiatan yang dapat ditampung disini, gang ini cukup democratic. Gang ini juga sangat berarti karena secara periodik digunakan untuk pertemuan warga dan setiap harinya digunakan untuk anakanak bermain.

Setting warga di gang RT 04 juga ketika warga berinteraksi dengan tetangga (duduk-duduk di kursi panjang sambil bercakap-cakap dengan tetangga, ada yang sambil minum teh/wedangan dan anak-anak bermain di teras rumah bahkan terkadang di gang). 


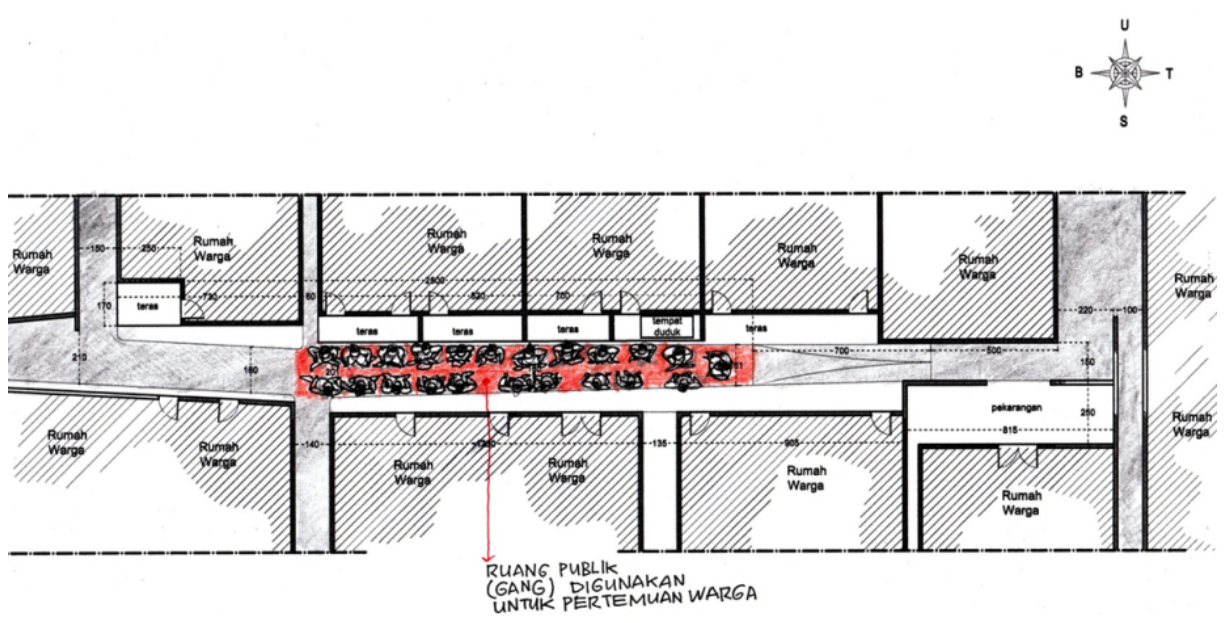

Gambar 13. Pemetaan perilaku warga menggunakan gang di RT 04, RW 01 (gang sebagai ruang pertemuan warga)

Sumber: Hasil analisis, 2018

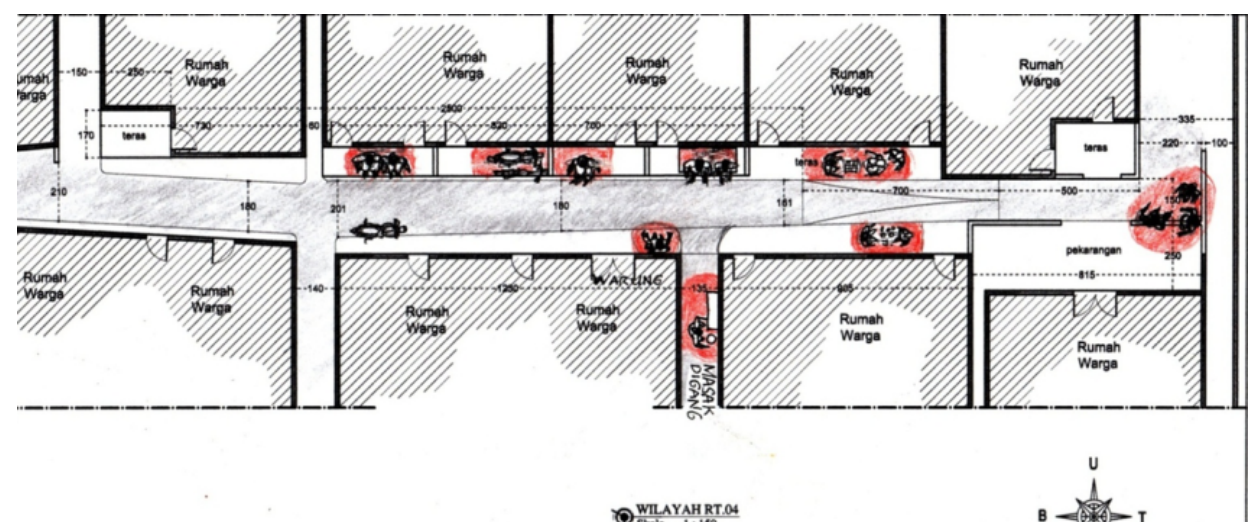

Gambar 14. Pemetaan perilaku warga menggunakan gang di RT 04, RW 01 (gang sebagai ruang sosialisasi dan ruang bermain anak-anak) Sumber: Hasil analisis, 2018

\section{Pemetaan Perilaku (Behavioral Mapping) Warga Menggunakan Gang di RT 05, RW 01}

Setting warga melakukan aktivitas di gang tepi sungai Winongo tepatnya di wilayah RT 05 RW 01 adalah terdapat beberapa fasilitas publik warga, diantaranya: pos ronda RT 05 , kantor RW 01, MCK umum dan angkringan. Ruang ini tiap hari digunakan untuk berkumpul dan beraktivitas warga., dapat dilihat pada gambar 15 berikut.

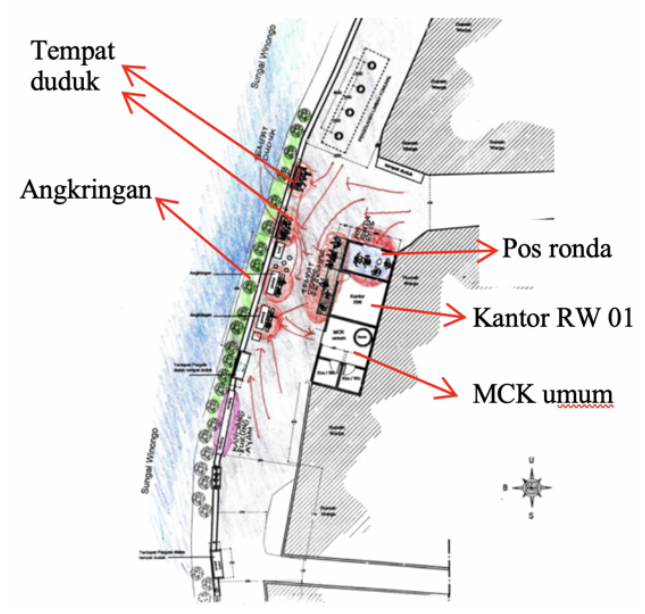

Gambar 15. Pemetaan perilaku warga menggunakan gang di RT 05, RW 01 Sumber: Hasil analisis, 2018 
Keberadaan ruang gang di tengahtengah perkampungan perkotaan sangat berperan dalam mengatasi kebutuhan ruang masyarakat untuk melakukan kegiatan. Disatu sisi pengguna sepeda motor, sepeda dan pejalan kaki terganggu karena ruang gang di gunakan untuk menjemur pakaian, parkir sepeda motor, memasak dan untuk berinteraksi masyarakat.

Tabel berikut menunjukkan jenis, pelaku dan waktu kegiatan yang telah dipetakan di Kampung Serangan.

Tabel 1. Jenis, pelaku dan waktu kegiatan di Kampung Serangan

\begin{tabular}{llll}
\hline No. & \multicolumn{1}{c}{ Jenis Kegiatan } & \multicolumn{1}{c}{ Pelaku Kegiatan } & \multicolumn{1}{c}{ Waktu Berkegiatan } \\
\hline 1 & Menjemur pakaian & Perempuan dewasa & Pagi jam 07.00 \\
\hline 2 & Interaksi sosial & $\begin{array}{l}\text { Laki-laki dewasa, perempuan } \\
\text { dewasa }\end{array}$ & $\begin{array}{l}\text { Sore jam 15.00-17.30, } \\
\text { malam jam 18.00-21.30 }\end{array}$ \\
\hline 3 & Interaksi sosial & $\begin{array}{l}\text { Laki-laki muda, perempuan } \\
\text { muda }\end{array}$ & $\begin{array}{l}\text { Sore jam 15.00-17.30, } \\
\text { malam jam 18.00-21.30. }\end{array}$ \\
\hline 4 & Bermain & Laki-laki dan perempuan & Sore jam 15.00-17.30 \\
\hline 5 & Memasak & Perempuan dewasa & $\begin{array}{l}\text { Pagi jam 07.00, sore jam } \\
16.00\end{array}$ \\
\hline 6 & Parkir motor & $\begin{array}{l}\text { Laki-laki muda dan dewasa, } \\
\text { perempuan muda dan dewasa }\end{array}$ & Sore jam 15.00-21.00 \\
\hline
\end{tabular}

Sumber: Hasil analisis, 2018

\section{Kesimpulan}

Ruang gang dapat menjadi solusi dalam memenuhi kebutuhan ruang untuk beraktivitas warga kampung perkotaan. Setiap hari warga melakukan interaksi sosial setidaknya tiga puluh menit bahkan berjam-jam dengan tetangganya. Tempat-tempat seperti jalan lingkungan/ gang (tepi gang) merupakan orientasi warga beraktivitas. Gang merupakan tempat yang umum digunakan berkumpul warga: anak-anak, pemuda pemudi dan orang tua laki-laki maupun perempuan. Kegiatan berkumpul ini biasanya dilakukan sore dan malam hari. Dengan demikian, gang merupakan kebutuhan tempat kontak sosial dengan tetangga di kampung perkotaan. Hal ini menunjukan adanya rasa tenggang rasa dan tingkat hubungan toleransi antar tetangga yang sangat baik. Interaksi sosial yang sifatnya lebih formal dilakukan pada pertemuanpertemuan Rukun Tetangga (RT), Rukun Warga (RW) di kampung atau pertemuan ibu-ibu (pertemuan PKK).
Keeratan hubungan antar tetangga juga ditunjukkan dalam interaksi sosial yang dilakukan di gang, diantara pemukiman. Di tempat ini, sebuah keluarga dapat mengenal dengan baik sejumlah besar keluarga-keluarga lain disekitarnya. Hal ini sangat berlainan dengan lingkungan perumahan menengah keatas di kota, dimana sebuah keluarga mungkin hanya mengenal dengan baik tiga atau empat keluarga di sekitarnya. Mengenal banyak tetangga mungkin sangat penting bagi masyarakat yang tinggal di daerah pemukiman seperti di area studi karena kegiatan sehari-hari dan pemeliharaan ruang-ruang bersama harus dilakukan secara bersama (komunal).

Karakter toleransi penduduk tampak dari perilaku mereka dalam berhubungan sosial, misalnya dalam penggunaan gang sebagai tempat parkir motor bersama, kegiatan memasak ketika tetangganya lewat menghampiri dan diajak bercakap- 
cakap, menjemur pakaian di tepi gang. Hal ini menunjukan masih adanya toleransi dan nilai gotong-royong yang tinggi. Koentjaraningrat (1974) lebih jauh mengatakan bahwa satu dari elemen gotong-royong adalah pola ketergantungan seseorang terhadap masyarakatnya. Suatu perasaan bahwa dirinya merupakan bagian dari masyarakat sekitarnya yang lebih luas, sehingga seseorang memerlukan penerimaan dari anggota masyarakat lainnya. Oleh karena itu, hubungan sosial dengan tetangga merupakan faktor penting dari tradisi gotongroyong. Di perkampungan di Serangan ini, tradisi gotong-royong, musyawarah warga di masing-masing Rukun Tetangga masih berlaku, yang ditunjukkan dengan masih tingginya tingkat toleransi dan tolong-menolong antar masyarakat.

Dengan demikian, dapat disimpulkan bahwa ada rasa kebersamaan, tenggang rasa, toleransi dalam pemakaian gang. Musyawarah warga di wilayah RT (Rukun Tetangga) merupakan sarana dalam membahas dan memutuskan persoalan-persoalan yang ada di wilayahnya, dilakukan secara berkala dan berjalan baik, yang didasarkan pada nilai kebersamaan. Hubungan sosial dan kekerabatan dengan tetangga sangat penting dan mempengaruhi masyarakat untuk mampu hidup di daerah pemukiman kampung kota dengan keterbatasan ruang dan sumber daya lingkungan. Karakter toleransi antar masyarakat di kampung Serangan ini dapat dimanfaatkan untuk tujuan pembangunan. Keterikatan antar anggota masyarakat dapat dikembangkan ke dalam programprogram partisipatif pembangunan untuk penanganan lingkungan permukiman perkotaan, khususnya dalam hal penanganan kekumuhan. Sedangkan program perbaikan kampung dapat difokuskan pada penanganan perbaikan fisik. Adanya pertisipasi masyarakat ini merupakan salah satu dari kesuksesan programprogram pembangunan atau perbaikan kampung kota.

\section{Daftar Pustaka}

Barker, R. (1968). Ecological psychology: Concepts and methods for studying the environment of human behavior. Stanford, California: Stanford University Press.

Cresswell, J.W. (2010). Research design: Pendekatan kualitatif, kuantitatif dan mixed. Yogyakarta: PT. Pustaka Pelajar.

Koentjaraningrat. (1974). Kebudayaan, mentalitas dan pembangunan. Jakarta: PT. Gramedia.

Laurens, J.M. (2004). Arsitektur dan perilaku manusia. Jakarta: PT. Gramedia Widiasarana Indonesia bekerja sama dengan Universitas Kristen Petra Surabaya.

McCall, G.J. dan Simmons, J.L. (1969). Issues in participant observation: A text and reader. Boston, Massachusetts, Amerika Serikat: Addison-Wesley Publishing Company.

Sommer, R. (1969). Personal space: The behavioral basis of design. Engelwood Cliff, New York: Prentice Hall.

Sudradjat, I. (2016). Penelitian kualitatif dalam disertasi arsitektur. Forum Diskusi IV Metodologi Penelitian Disertasi Arsitektur. Universitas

Parahyangan Bandung dan Universitas Atma Jaya Yogyakarta. 